\title{
Quantitative trait loci affecting milk production traits on bovine chromosome 6 in zebuine Gyr breed
}

\author{
A. A. Silva, ${ }^{\star}$ A. L. S. Azevedo, $†$ R. S. Verneque, K. Gasparini,† M. G. C. D. Peixoto, $†$ M. V. G. B. da Silva, $†$ \\ P. S. Lopes, ${ }^{*}$ S. E. F. Guimarães, ${ }^{* 1}$ and M. A. Machado† \\ *Departamento de Zootecnia, Universidade Federal de Viçosa, 36570-000, Viçosa, MG, Brazil \\ †Embrapa Gado de Leite, Rua Eugênio do Nascimento 610, Dom Bosco, 36038-330, Juiz de Fora, MG, Brazil
}

\begin{abstract}
Fourteen Brazilian dairy Gyr sire families with 657 daughters were analyzed for quantitative trait loci (QTL) on chromosome 6 by using a daughter design for 5 economic traits: milk, fat, and protein production, fat and protein percentage. The cows and sires were genotyped for 27 microsatellites with average spacing between markers of $4.9 \mathrm{cM}$. In the analyses across 14 families, for the largest significant families, and within family, a QTL was located for milk yield and fat yield close to marker BMS2508 at the 5\% chromosome-wide significance level across families and 1\% chromosomewide within families. For fat percentage, a QTL near DIK4482 was identified at the $5 \%$ chromosome-wide significance level when all families were analyzed together and at the $1 \%$ chromosome-wide significance level within the largest significant families. The different analyses yielded results that were generally consistent for milk yield, fat yield, and fat percentage. The order of the markers in the derived map was consistent with that in the consensus map. Some QTL and candidate genes in dairy cattle for milk production traits are probably preserved in Bos taurus and Bos indicus.
\end{abstract}

Key words: Bos indicus, dairy cattle, daughter design

\section{INTRODUCTION}

In tropical countries, the Gyr cattle breed (Bos indicus) is very important because of its tolerance of heat and parasites and because it is essential to the breeding of Girolando cattle (5/8 Holstein: 3/8 Gyr). Girolando cattle are characterized by hybrid vigor. They show the rusticity and adaptation to the tropics particular to the Gyr breed and the good milk production traits of the Holstein and comprise $70 \%$ of all dairy cows in Brazil. The dairy Gyr is much better adapted to the climate

Received December 3, 2009.

Accepted October 21, 2010.

${ }^{1}$ Corresponding author: sfacioni@ufv.br in Brazil than are the European cattle breeds, and it has crucial qualities for efficient milk production in the tropics. The Brazilian Gyr was imported from India in the 1930s and introduced to herds that were aimed at meat production. Later, in the 1960s, some breeders of Gyr cattle began selection for milk production. Although the number of animals imported was relatively small, these animals adapted very well to the Brazilian environment and multiplied rapidly (Santiago, 1985). Breeding programs for the most economically important traits of Zebu dairy cattle have been introduced recently in Brazil, and the Gyr breed was the first Zebu breed, not only in Brazil but also throughout the world, with a program for genetic evaluation of dairy traits. The first genetic evaluation of dairy Gyr in a progeny test was published in 1993 by Embrapa (Empresa Brasileira de Pesquisa Agropecuária, Brasilia, Brazil) and 17 annual evaluations have now been conducted (Verneque et al., 2009).

Several studies have shown that QTL can be detected and mapped in populations of commercial dairy cattle by application of a daughter design (Lipkin et al., 1998; Ron et al., 2001; Chen et al., 2006). These studies have found a large number of QTL that affect milk production, and all 29 bovine autosomes are thought to harbor QTL for these traits (i.e., milk yield, protein yield and percentage, and fat yield and percentage; Khatkar et al., 2004). Several studies have reported the presence of QTL on chromosome 6; these reports show similarities but also some differences across families in the level of significance, effect size, location of QTL, significance threshold, design methodologies, and so on.

Segregating QTL for milk production traits on BTA6 have been found mainly in the Holstein breed of dairy cattle: in US Holsteins (Georges et al., 1995; Zhang et al., 1998), Dutch Holsteins (Spelman et al., 1996), German Holsteins (Kühn et al., 1999; Freyer et al., 2003), Israeli Holsteins (Lipkin et al., 1998; Ron et al., 2001), and Chinese Holsteins (Chen et al., 2006). Other QTL mapping studies in dairy cattle have been implemented in populations of Finnish Ayrshire (Velmala et al., 1999), Norwegian cattle (Olsen et al., 2004 and 
Table 1. Family name, number and percentage of daughters per family used in the analyses

\begin{tabular}{lrc}
\hline & \multicolumn{2}{c}{ Daughters } \\
\cline { 2 - 3 } Family & No. & $\%$ \\
\hline 1 & 127 & 19.3 \\
2 & 94 & 14.3 \\
3 & 68 & 10.4 \\
4 & 62 & 9.4 \\
5 & 59 & 8.9 \\
6 & 46 & 7.0 \\
7 & 34 & 5.2 \\
8 & 28 & 4.3 \\
9 & 28 & 4.3 \\
10 & 24 & 3.6 \\
11 & 23 & 3.5 \\
12 & 22 & 3.3 \\
13 & 22 & 3.3 \\
Total & 20 & 3.0 \\
\hline
\end{tabular}

2005), and British Black and White cattle (Wiener et al., 2000), but all studies were done in breeds of Bos taurus. This was probably in part because of the need for large families to employ daughter or granddaughter designs.

A major objective of QTL studies is to find genes or markers that can be implemented in breeding programs by marker-assisted selection (MAS). In dairy cattle, MAS can be used to preselect young candidate bulls before progeny testing, thus increasing selection differentials, shortening the generation interval, and increasing genetic gain (Khatkar et al., 2004). The aim of the present study was to map QTL for milk production and milk composition traits on chromosome 6 in Brazilian dairy Gyr families by using the daughter design on data from the most important bulls in Embrapa's Genetic Evaluation Program. Although the population size of dairy Gyr is relatively small compared with that of Holsteins and other Bos taurus breeds of dairy cattle, this work represents the first QTL report in Bos indicus dairy breeds.

\section{MATERIALS AND METHODS}

\section{Population Sample}

Blood samples were collected from over 750 Brazilian dairy Gyr cows from different herds, which were daughters of 14 of the most important sires of this breed. Semen samples were collected from the 14 sires. The cows were analyzed for 27 microsatellite genetic markers on chromosome 6. Daughters were considered to be informative if their genotype was different from that of their sire (Ron et al., 1996). Cows that did not inherit the paternal allele for more than 2 marker loci were not considered to be daughters of the assigned sire and were, therefore, not considered for the QTL analysis. Cows without genetic evaluations for the 5 production traits were also deleted from the analysis, as were sire families with fewer than 20 daughters. The total number of sire families used in the analysis, and the total and informative number of daughters per sire family are given in Table 1.

\section{Marker Data}

Twenty-seven microsatellite markers were selected from bovine chromosome 6 , according to the Meat Animal Research Center (MARC; Clay Center, NE) map (Ihara et al., 2004). The average distance between markers was $4.9 \mathrm{cM}$ and ranged from 0.0 to $130.8 \mathrm{cM}$. Markers were chosen based on their positions (cM), number of alleles, and level of polymorphic information content. The marker order and map distances among markers were estimated with the "fixed" option of the CRIMAP 2.4 program (Green et al., 1990); the map distances were based on Kosambi's mapping function. Although the 27 markers covered $134.5 \mathrm{cM}$, the order of markers achieved was generally consistent with the MARC map. The differences in the estimated frequency of recombination were not expected to introduce bias in the test for QTL or the estimates of QTL effects (Haley and Knott, 1992); therefore, the MARC map was used in this work.

Samples of DNA were extracted from semen and blood using a protocol described by Sambrook and Russel (2001), with modifications. The PCR reaction was performed in a thermocycler using $45 \mathrm{ng}$ of template DNA, $0.2 \mathrm{~m} M$ of dNTPs, $20 \mathrm{~m} M$ of Tris, pH 8.3, $50 \mathrm{mM}$ of $\mathrm{KCl}$, and $0.1 \mu M$ of each primer; the $\mathrm{MgCl}_{2}$ concentration was determined for each marker. Forward primers were labeled with fluorescent dye (FAM, HEX, or TAMRA). The annealing temperatures for the PCR ranged from 50 to $58^{\circ} \mathrm{C}$, and the program consisted of $94^{\circ} \mathrm{C}(1 \mathrm{~min})$, annealing temperature $(1 \mathrm{~min}), 72^{\circ} \mathrm{C}$ (1 min) for 35 cycles, and one general extension for $45 \mathrm{~min}$ at $72^{\circ} \mathrm{C}$. The $\mathrm{PCR}$ reactions were run on the MegaBace DNA sequencer (GE Healthcare, HYSE, Munich, Germany). Automated fragment analysis, size calling, and binning were then assessed using Fragment Profiler software. The markers that were genotyped on chromosome 6, their map location, number of alleles, and the number of heterozygous sires for each marker are given in Table 2 .

\section{Phenotypic Records}

Improvement of milk traits in dairy Gyr cattle is based on the use of genetically superior sires in herds 
Table 2. The map locations of the markers genotyped on chromosome 6, with number of alleles and number of heterozygous sires for each marker

\begin{tabular}{|c|c|c|c|c|c|}
\hline No. & Marker & $\begin{array}{l}\text { Map location }{ }^{1} \\
(\mathrm{cM})\end{array}$ & $\begin{array}{c}\text { Alleles } \\
\text { MARC }^{2}(\mathrm{n})\end{array}$ & $\begin{array}{c}\text { Alleles } \\
\text { PNMGL }^{3} \text { (n) }\end{array}$ & $\begin{array}{l}\text { Heterozygous } \\
\text { sires (n) }\end{array}$ \\
\hline 1 & ILST093 & 0.0 & 21 & 9 & 11 \\
\hline 2 & DI4408 & 9.0 & 9 & 12 & 11 \\
\hline 3 & DIK5285 & 15.3 & 7 & 17 & 13 \\
\hline 4 & DIK4498 & 20.1 & 8 & 8 & 8 \\
\hline 5 & MNB66 & 29.3 & 11 & 12 & 12 \\
\hline 6 & BM1329 & 35.4 & 9 & 11 & 8 \\
\hline 7 & DIK1058 & 38.2 & 7 & 8 & 12 \\
\hline 8 & BMS2508 & 44.0 & 9 & 8 & 14 \\
\hline 9 & DIK4382 & 50.1 & 10 & 14 & 13 \\
\hline 10 & DIK4482 & 54.5 & 7 & 8 & 10 \\
\hline 11 & MNB-208 & 60.2 & 7 & 9 & 11 \\
\hline 12 & BM4322 & 63.9 & 6 & 12 & 8 \\
\hline 13 & BMS470 & 67.4 & 9 & 9 & 10 \\
\hline 14 & DIK3026 & 71.5 & 9 & 9 & 11 \\
\hline 15 & DIK2294 & 75.3 & 10 & 17 & 13 \\
\hline 16 & DIK4867 & 82.0 & 7 & 8 & 7 \\
\hline 17 & ILSTS035 & 87.3 & 19 & 18 & 10 \\
\hline 18 & DIK4574 & 90.5 & 10 & 6 & 8 \\
\hline 19 & BMS5021 & 93.8 & 8 & 11 & 10 \\
\hline 20 & AFR227 & 97.0 & 11 & 11 & 10 \\
\hline 21 & DIK 2174 & 101.4 & 5 & 8 & 12 \\
\hline 22 & DIK4827 & 107.1 & 7 & 10 & 13 \\
\hline 23 & DIK2995 & 109.9 & 5 & 6 & 12 \\
\hline 24 & DIK1182 & 115.3 & 14 & 9 & 10 \\
\hline 25 & DIK2690 & 121.5 & $\begin{array}{r}14 \\
4\end{array}$ & 8 & 11 \\
\hline 26 & BM2320 & 127.5 & 10 & 21 & 13 \\
\hline 27 & DIK4992 & 130.8 & 4 & 7 & 7 \\
\hline
\end{tabular}

${ }^{1}$ The USDA Meat Animal Research Center (MARC) map (Ihara et al., 2004).

${ }^{2}$ USDA/MARC map.

${ }^{3}$ Brazilian National Dairy Gyr Genetic Improvement Program (Embrapa, Brasilia, Brazil).

belonging to the Brazilian National Dairy Gyr Genetic Improvement Program developed by Embrapa. These sires are often evaluated in progeny test programs using the BLUP (Henderson, 1984) animal models (Martinez et al., 2005; Verneque et al., 2009). Phenotypic data on the production traits milk yield (MY), protein yield $(\mathbf{P Y})$, fat yield $(\mathbf{F Y})$, protein percentage $(\mathbf{P P})$, and fat percentage $(\mathbf{F P})$ were obtained from the National Zootechnical Archive for the Brazilian Dairy Gyr, also developed by Embrapa. These traits, recorded over 305 $\mathrm{d}$ and preadjusted for calving age and month, were analyzed using the repeatability animal model (Verneque et al., 2009).

The EBV from the evaluations made in 2008 were used as the phenotypic data for this work. Means, stan- dard deviations, and minimum and maximum values of the EBV of the cows are given in Table 3.

\section{Statistical Analysis for QTL Mapping}

Weller et al. (1990) proposed the use of the granddaughter design and daughter design as methods for detection of QTL in dairy cattle. For the daughter design, genotypic information is recorded for sires and their daughters, with phenotypic observations made on the daughters.

The linkage analysis was executed by a regression approach described by Knott et al. (1996) and used the web-based software GridQTL (http://www.gridqtl.org. uk; Seaton et al., 2006). The EBV were adjusted for

Table 3. Means, standard deviations, and minimum and maximum values of EBV of the cows genotyped for the traits analyzed

\begin{tabular}{lcccc}
\hline Trait & Mean & SD & Minimum & Maximum \\
\hline Milk yield (kg) & 679.43 & 404.05 & -330.8 & $1,720.8$ \\
Fat yield (kg) & 22.47 & 16.23 & -15.40 & 84.60 \\
Protein yield $(\mathrm{kg})$ & 12.34 & 11.59 & -12.30 & 56.20 \\
Fat percentage (\%) & -0.038 & 0.101 & -0.315 & 0.329 \\
Protein percentage (\%) & -0.012 & 0.050 & -0.189 & 0.139 \\
\hline
\end{tabular}


Table 4. Quantitative trait loci location, nearest marker, $F$-value, $5 \%$ chromosome-wide threshold, and $95 \%$ CI of QTL position in the analysis across 14 families

\begin{tabular}{lclccr}
\hline Trait $^{1}$ & $\begin{array}{c}\text { Location } \\
(\mathrm{cM})\end{array}$ & $\begin{array}{l}\text { Nearest } \\
\text { marker }\end{array}$ & $F$-value & $\begin{array}{c}\text { F-threshold } \\
(5 \%)\end{array}$ & \multicolumn{1}{c}{$\begin{array}{c}95 \% \text { CI } \\
(\mathrm{cM})\end{array}$} \\
\hline MY & 46 & BMS2508 & 2.42 & 2.37 & $22-129$ \\
FY & 46 & BMS2508 & 3.27 & 2.90 & $18-115$ \\
PY & 44 & BMS2508 & 2.55 & 2.74 & $6-102$ \\
FP & 56 & DIK4482 & 2.87 & 2.66 & $42-123$ \\
PP & 59 & MNB-208 & 1.57 & 2.31 & $7-130$ \\
\hline
\end{tabular}

${ }^{1} \mathrm{MY}=$ milk yield; $\mathrm{FY}=$ fat yield $\mathrm{PY}=$ protein yield $\mathrm{FP}=$ fat percentage and $\mathrm{PP}=$ protein percentage.

trait reliability by using weighted least squares. The QTL analysis was done using the linear model

$$
\mathrm{wBV}_{i j k}=S_{i j}+b_{i j l} x_{j k l}+\mathrm{e}_{i j k l},
$$

where $\mathrm{wBV}_{i j k}$ is the weighted breeding value; $i=$ trait; $j=$ sire $;=$ daughter; $l=$ putative QTL position; $S$ is the effect of sire $j$ on trait $i ; x$ is the probability that daughter $k$ from sire $j$ received the chromosomal segment at position $l$ from paternal haplotype $1 ; b$ is the regression coefficient for trait $i$ of daughter $k$ from sire $j$ at position $l$; and $e$ is the random residual associated with each record.

The analyses were carried out across all families and within each family. Effects within families were identified as significant based on the absolute $t$-value $[\mathbf{A B S}(\boldsymbol{t})]$ with degrees of freedom equal to the number of informative daughters $(n)$ in the family, and when $\operatorname{ABS}(t)$ was higher than the critical value $\left(t_{0.05, \mathrm{n}}\right)$ for each family and trait. Each family was individually analyzed by using GridQTL to determine the sire's QTL segregation status for each trait.

Data permutation $(\mathrm{n}=10,000)$ was used to determine chromosome-wise significance levels for each sire (Churchill and Doerge, 1994). Tests of 1 versus 0 QTL were conducted individually for each family. Sires significant at the chromosome-wise $P<0.05$ level for the 1-QTL model were classified as segregating, regardless of trait or QTL position. Data for all segregating sires were combined into a data set. Across-family analysis was performed on this data set, and bootstrapping ( $n$ $=10,000)$ was used to obtain confidence intervals for QTL location.

The variance of the BV explained by the QTL was determined using the formula described by (Kim et al., 2003):

$h_{Q T L}^{2}=\left[100 \times\left(\right.\right.$ residual $\mathrm{SS}_{\mathrm{H}_{0}}-$ residual $\left.\mathrm{SS}_{\mathrm{H}_{\mathrm{a}}}\right) /\left(\right.$ residual $\left.\left.\mathrm{SS}_{\mathrm{H}_{0}}\right)\right]$, where SS is the sum of squares, with $\mathrm{H}_{0}$ being the noQTL model and $H_{a}$ being the 1-QTL model.

\section{RESULTS}

\section{Information Content}

The marker information content on chromosome 6 is plotted in Figure 1; it was calculated from the variance of the conditional probabilities of inheriting a chromosomal region at each centimorgan as a proportion of the variance when the true descent is known (Chen et al., 2006). The high heterozygosity of marker ILST035 $\left(\mathrm{H}_{0}=0.820\right)$ and the small distances between ILST035 $(87.26 \mathrm{cM})$ and the 6 adjacent markers resulted in greater information content for family 3 for this interval. On the other hand, the low heterozygosity of marker DIK4498 $\left(\mathrm{H}_{0}=0.461\right)$ and the large distances between DIK4498 and the 6 adjacent markers for this interval resulted in less information content for families 3,4 , and 11 .

\section{Analysis Across Families}

The results for the 5 traits across all families are given in Table 4. The test statistics for MY $(F=2.42)$, FY $(F=3.27)$, and FP $(F=2.87)$ were greater than $5 \%$ chromosome-wide. The widths of the $95 \%$ CI estimated by bootstrapping ranged from 81 to $123 \mathrm{cM}$ for all traits. The peaks for traits MY and FY were located between the markers BMS2508 and DIK4382. The peak for trait FP appeared between the markers DIK4382 and MNB-208 (Figure 2).

For the sire of family number 3, QTL effects were identified on MY, FY, and FP. Significant QTL effects for MY were detected for family 9 and effects on FP were also detected for families 4 and 11 . The $F$-value, the $5 \%$ chromosome-wide threshold, significant families for the 5 milk production traits, the substitution effect, standard deviation (SE), and $\operatorname{ABS}(t)$ are shown in Table 5. 


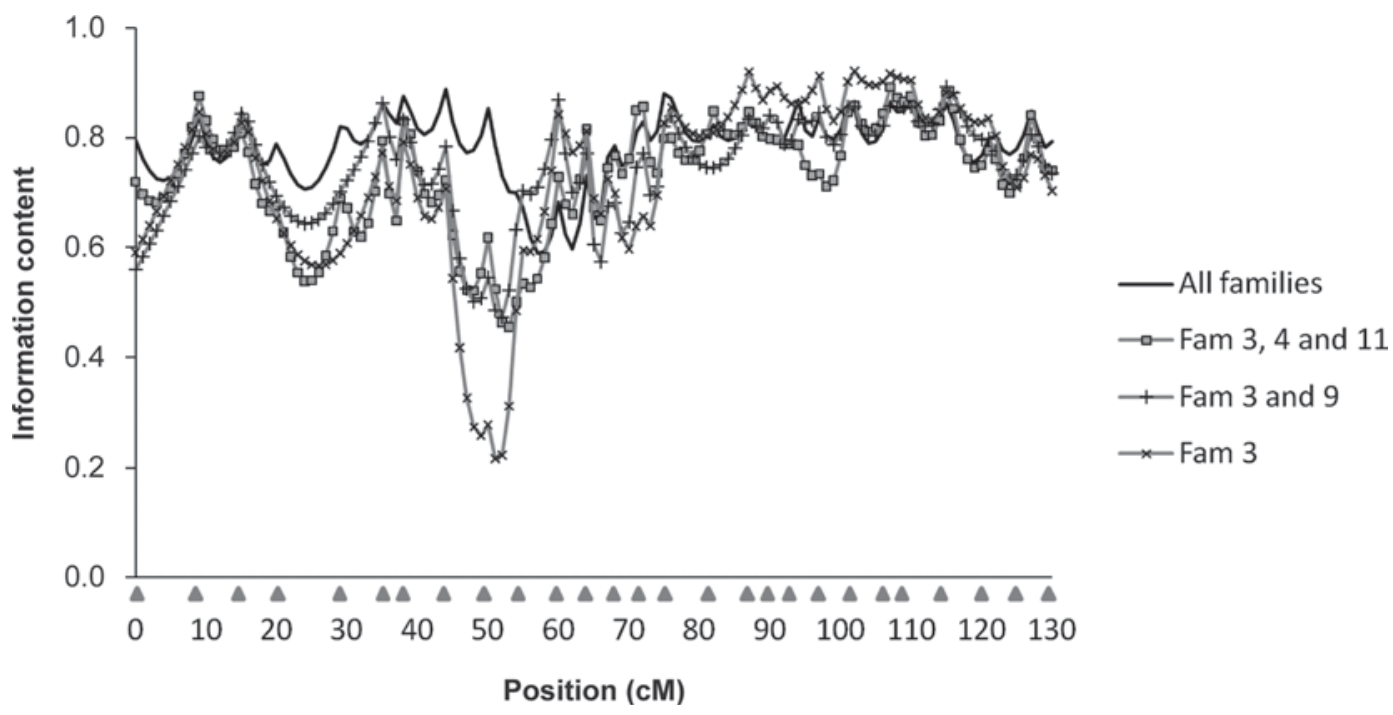

Figure 1. Information content across all families; within families 3, 4, and 11; within families 3 and 9; and within family 3 . Arrowheads indicate markers location on the chromosome.

In Figure 3, the test statistic ( $F$-value) is shown for the traits MY, FY, and FP across significant families. The highest peak for the 3 traits was for FY, which was located near position $46 \mathrm{cM}$ close to marker BMS2508, and the lowest peak was for FP, located near position $50 \mathrm{cM}$ close to marker DIK4382. With respect to the other peaks, MY was located near position $46 \mathrm{cM}$, close to marker BMS2508.

\section{Analysis Within Family}

Analyses were carried out within families for each of the 6 families listed in Table 5. Within families 3, 4, and 9 , the information content (Figure 1) fluctuated more than across all the 14 families together. In family 3, the information content was greater than across the 14 families in the interval between markers DIK4482 and

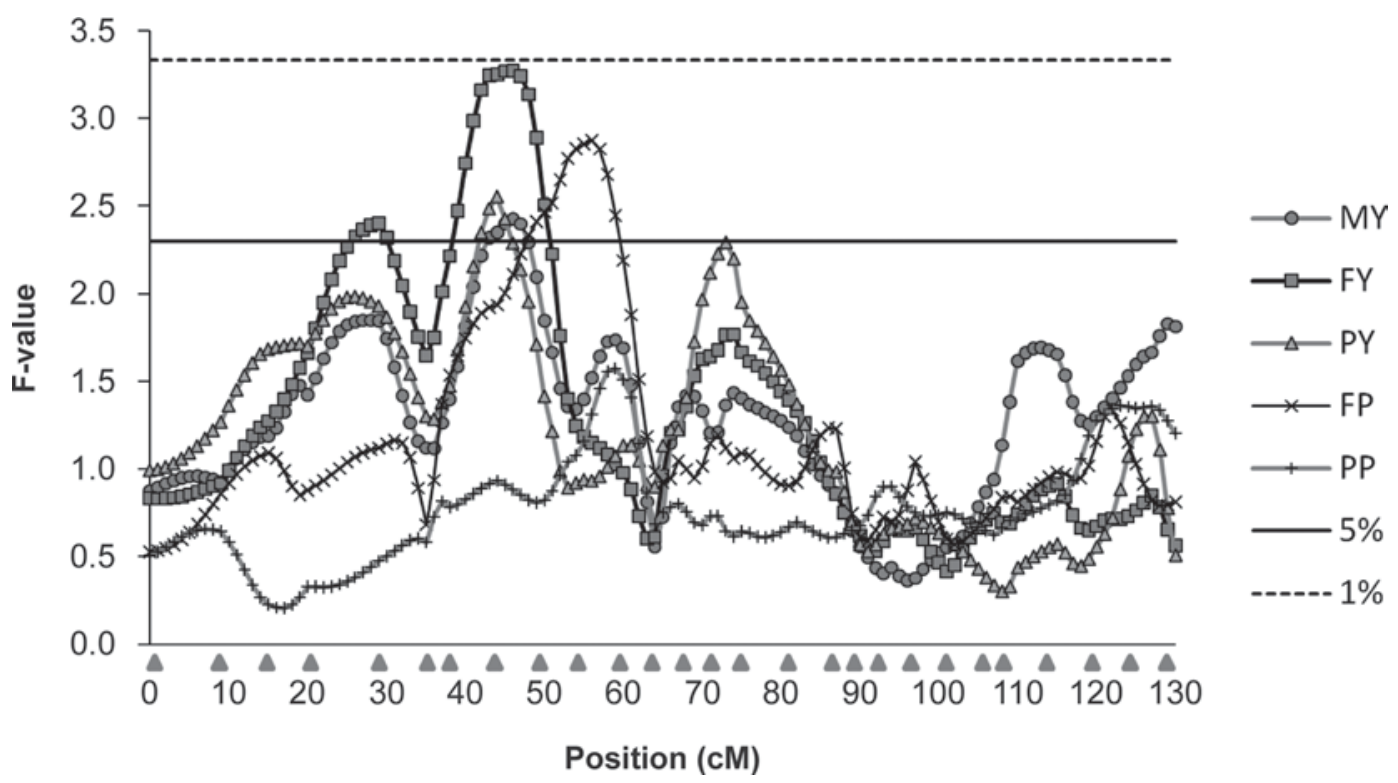

Figure 2. $F$-values for the analysis across 14 families for milk yield (MY), fat yield (FY), protein yield (PY), fat percentage (FP), and protein percentage (PP). Arrowheads indicate markers location on the chromosome; the straight line indicates the 5\% chromosome-wide threshold for MY. 
Table 5. Quantitative trait loci location, nearest marker, $F$-value, 1\% chromosome-wide threshold, significant family, substitution effect, SE, and $t$-value

\begin{tabular}{|c|c|c|c|c|c|c|c|c|}
\hline Trait $^{1}$ & $\begin{array}{c}\text { Location } \\
(\mathrm{cM})\end{array}$ & $\begin{array}{l}\text { Nearest } \\
\text { marker }\end{array}$ & $F$-value & $\begin{array}{c}F \text {-threshold } \\
1 \%\end{array}$ & Family & Effect $^{2}$ & $\mathrm{SE}$ & $\operatorname{ABS}(t)^{3}$ \\
\hline MY & 47 & BMS2508 & 9.16 & 7.68 & 3 & 388.99 & 134.88 & 2.88 \\
\hline FY & 49 & DIK4382 & 15.85 & 12.48 & 3 & 19.60 & 4.923 & 3.98 \\
\hline PY & 43 & BMS2508 & 9.85 & 14.80 & 8 & -12.75 & 4.042 & 3.12 \\
\hline \multirow[t]{2}{*}{$\mathrm{FP}$} & 50 & DIK4382 & 9.04 & 10.10 & 4 & 0.077 & 0.025 & 3.03 \\
\hline & & & & & 11 & 0.120 & 0.040 & 2.97 \\
\hline
\end{tabular}

${ }^{1} \mathrm{MY}=$ milk yield $\mathrm{FY}=$ fat yield $\mathrm{PY}=$ protein yield; $\mathrm{FP}=$ fat percentage; and $\mathrm{PP}=$ protein percentage.

${ }^{2}$ Marker allele substitution effect.

${ }^{3}$ Absolute $t$-value; significance of the within-family effect of paternal marker allele.

BM4322 and between DIK4867 and DIK4827. In this family, the significant peaks and $F$-values were superior to $1 \%$ chromosome-wide level for FY and FP (Table 6). The $F$-value for PY was $>5 \%$ chromosome-wide, and the $F$-values for MY and PP were $<5 \%$ chromosomewide (Figure 4). The nearest marker for FY and PY was DIK4382, and that for FP was MNB-208. The widths of the $95 \%$ CI for the QTL detected ranged from 22 (FP) to $94 \mathrm{cM}(\mathrm{PY})$.

Within family 4 , only 1 significant peak was identified, which was for FP and was located at $55 \mathrm{cM}$, close to marker DIK4482; it had an $F$-value above $1 \%$ chromosome-wide. For the traits MY, FY, PY, and PP, the $F$-values were lower than $5 \%$ chromosome-wide (Figure 5 and Table 6 ). The widths of the $95 \%$ CI ranged from 52.5 to $130 \mathrm{cM}$. The significant peak for family 9 was for MY, which was located at $45 \mathrm{cM}$, close to marker
BMS2508 and had an $F$-value $>1 \%$ chromosome-wide. For the other traits, the $F$-values were $<5 \%$ chromosome-wide, and the widths of the $95 \%$ CI ranged from 65 to $124 \mathrm{cM}$ (Figure 6 and Table 6).

\section{DISCUSSION}

In dairy cattle most emphasis has been placed on the detection of QTL that affect milk production, and all autosomes are thought to harbor QTL that affect milk production traits (Khatkar et al., 2004). Consequently, a large number of studies have been carried out to date that involve QTL mapping for milk production traits on chromosome 6 in Bos taurus, but studies in Bos indicus are also necessary to map QTL and eventually to identify the genes themselves. Even moderate-sized populations can provide the appropriate population

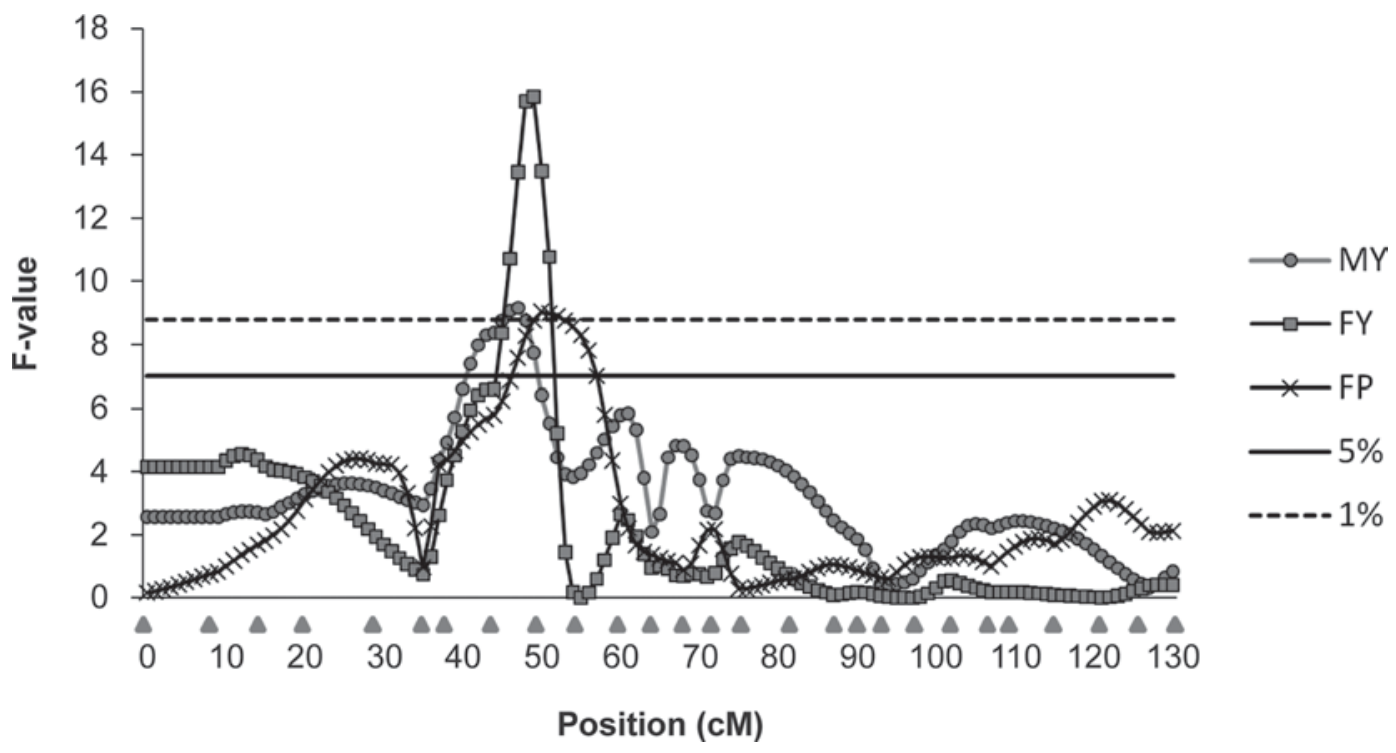

Figure 3. F-values for the analysis of significant families for milk yield (MY), fat yield (FY), and fat percentage (FP). Arrowheads indicate markers location on the chromosome; the dotted line indicates the $1 \%$ chromosome-wide threshold for MY. 


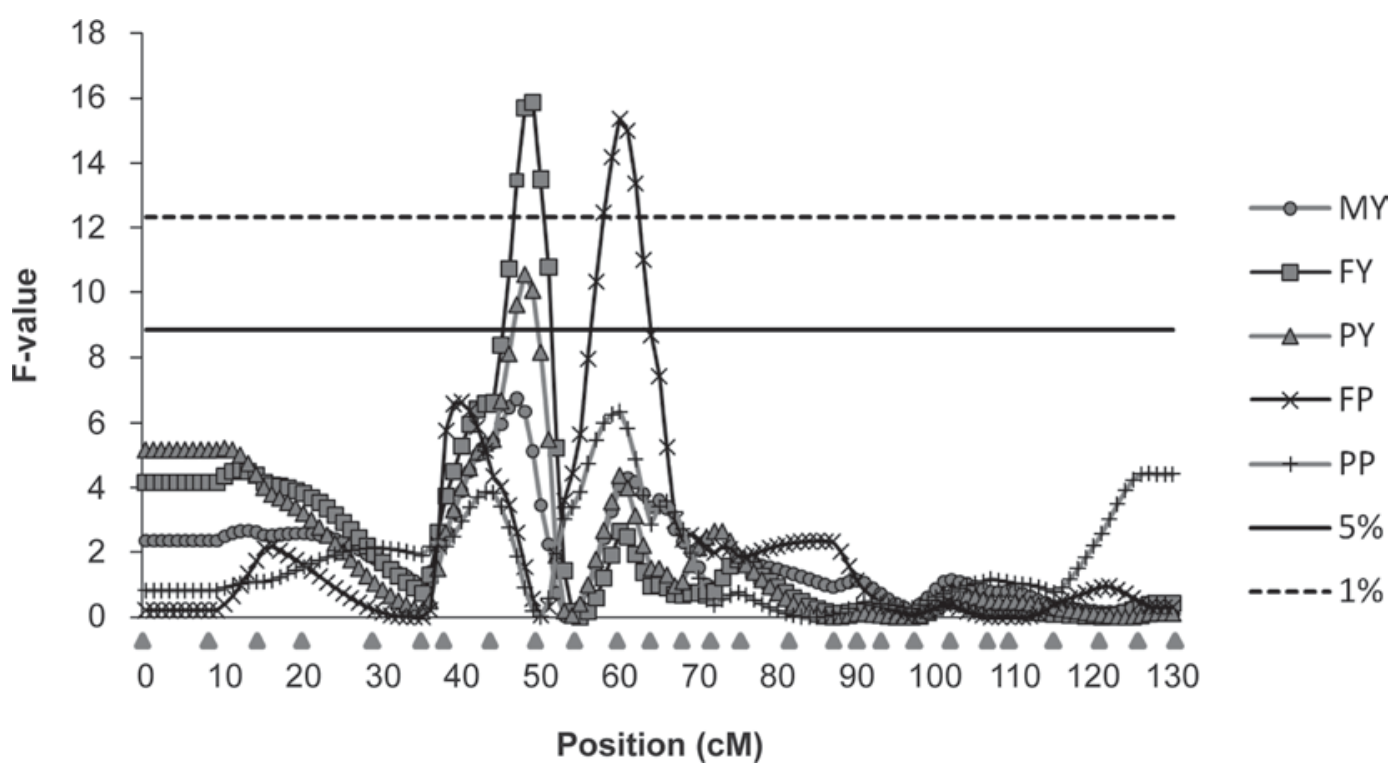

Figure 4. F-values for milk yield (MY), fat yield (FY), protein yield (PY), fat percentage (FP), and protein percentage (PP), from the analysis within family 3 . Arrowheads indicate markers location on the chromosome; the dotted line indicates the $1 \%$ chromosome-wide threshold for FP.

structure for the daughter design (several sires, each with a considerable number of daughters whose milk production has been recorded). For example, the progeny testing program for Brazilian dairy Gyr cattle began in 1985, and the first sire summary was published in 1993 (Verneque et al., 2009).

In the daughter design, only a fraction of the sires will be heterozygous for any particular marker, and therefore not all genotypes are informative (Ron et al., 2001). The mean number of heterozygous sires per marker in the present study was $10.6(75.7 \%)$, and the marker for which all 14 sires were heterozygous was
BMS2508, which was located at $43.93 \mathrm{cM}$. Ron et al. (2004) found $69 \%$ of heterozygous sires per marker in Israeli Holstein and Chen et al. (2006) found $62 \%$ in Chinese Holstein.

In the analyses across the 14 families, the $5 \%$ chromosome-wide significant peaks for the traits MY and FY were close to marker BMS2508; for FP, the peak was close to marker DIK4482 (Table 4). In the analyses performed in the most significant families, 3 and 9 (Figure 3), and within family 9 (Figure 6), the $F$-value for MY was $>1 \%$ chromosome-wide threshold, and the position was almost the same as those observed

Table 6. Location of QTL, nearest marker, F-value, $1 \%$ chromosome-wide threshold, and 95\% CI of QTL position after analyses within families 3 , 4 , and 9 for the 5 milk production traits

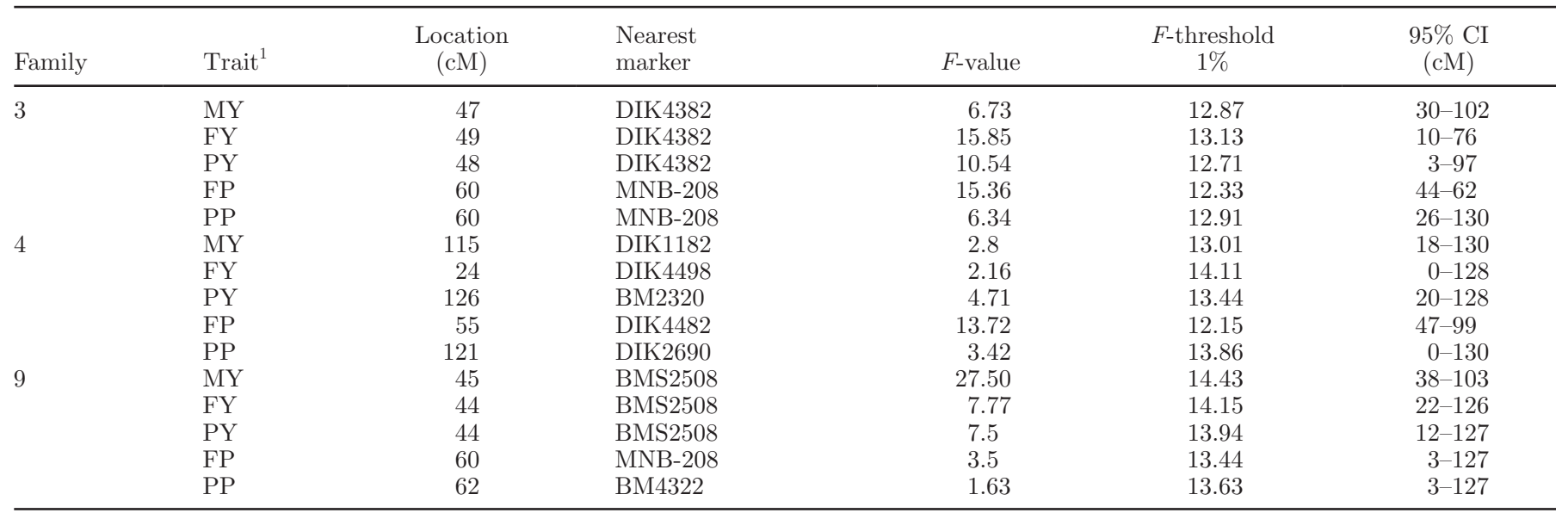

${ }^{1} \mathrm{MY}=$ milk yield; $\mathrm{FY}=$ fat yield $\mathrm{PY}=$ protein yield; $\mathrm{FP}=$ fat percentage; and $\mathrm{PP}=$ protein percentage. 


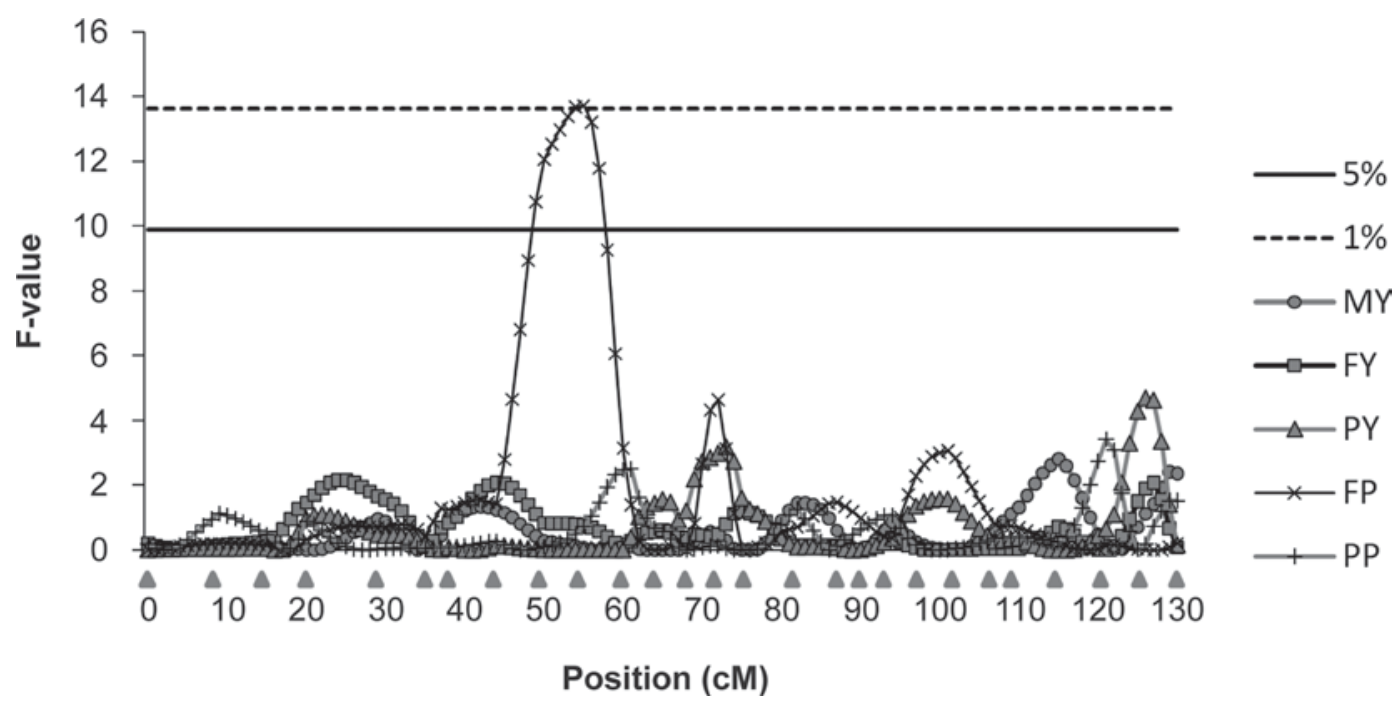

Figure 5. F-values for milk yield (MY), fat yield (FY), protein yield (PY), fat percentage (FP), and protein percentage (PP), from the analysis within family 4 . Arrowheads indicate markers location on the chromosome; the dotted line indicates the $1 \%$ chromosome-wide threshold for FP.

in the analyses across all 14 families. For trait FY, in the analysis across all 14 families (Figure 2) and within family 3 (Figure 4 ), the $F$-values exceeded the $5 \%$ and $1 \%$ chromosome-wide levels, respectively, and the FY peak was also located close to marker BMS2508. Thus, the analyses across and within families indicated QTL for $\mathrm{MY}$ and $\mathrm{FY}$ in the same region of the chromosome 6 (45 cM). Ron et al. (2001) reported a QTL for MY located at $47 \mathrm{cM}$, near BMS2508, and former studies in Norwegian dairy cattle have positioned a QTL that affects milk production traits in a $7.5-\mathrm{cM}$ interval surrounded by the microsatellites BMS2508 $(43.93 \mathrm{cM})$ and
FBN12 (51.43 cM) in the central part of BTA6. This QTL seems to be associated with major decreases in fat and protein percentage and a minor increase in milk yield (Olsen et al., 2002). In Norwegian dairy cattle, Olsen et al. (2004) reported a QTL with a large effect on milk production at an interval of $420 \mathrm{~kb}$ between the genes $A B C G 2$ and $L A P 3$ on BTA 6 . Other studies have reported QTL for MY in this region: Georges et al. (1995) identified a QTL at position $47 \mathrm{cM}$, Freyer et al. (2002) located a QTL at position $49 \mathrm{cM}$, and Khatkar et al. (2004) located a QTL at position $50 \mathrm{cM}$. In this same region, Cohen et al. (2004) identified a QTL for

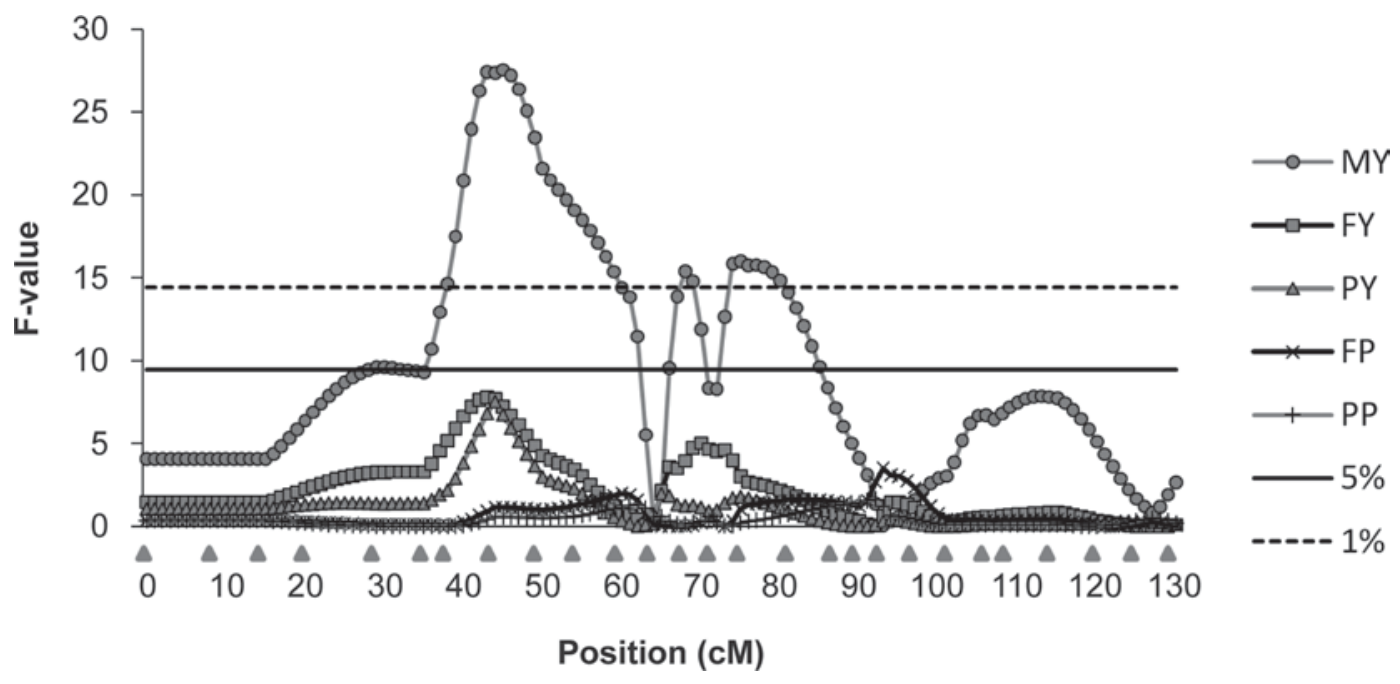

Figure 6. $F$-values for milk yield (MY), fat yield $(\mathrm{FY})$, protein yield $(\mathrm{PY})$, fat percentage $(\mathrm{FP})$, and protein percentage $(\mathrm{PP})$, from the analysis within family 9 . Arrowheads indicate markers location on the chromosome; the dotted line indicates the $1 \%$ chromosome-wide threshold for MY. 
FY at position $49 \mathrm{cM}$ and Ron et al. (2001) mapped a QTL at position $45 \mathrm{cM}$.

One QTL was detected for FP between markers DIK4482 and MNB208. Within family 3 (Figure 4) and within family 4 (Figure 5 ), the $F$-value for FP was above the $1 \%$ chromosome-wide threshold, and the position was almost the same as those observed in the analyses across all 14 families. Ron et al. (2001) reported 2 QTL for $\mathrm{FP}$ at positions 50 and $54 \mathrm{cM}$, near BM143. Georges et al. (1995) mapped a QTL for FP at position $51 \mathrm{cM}$ in dairy cattle by exploiting progeny testing. Boichard and Bishop (1997) identified an FP QTL at position 58 cM in Holstein cattle, and Ashwell et al. (2002) located a QTL at position $58 \mathrm{cM}$ in a US Holstein line. In the present study, the peak for $\mathrm{FP}$ was close to marker DIK4482 (54.51 cM) and located $0.79 \mathrm{cM}$ from marker BM143.

Various studies, performed in several breeds, have reported segregation of QTL close to marker BM143 in the central region of BTA6 (e.g., Spelman et al., 1996; Kühn et al., 1999; Velmala et al., 1999; Nadesalingam et al., 2001; Ron et al., 2001; Khatkar et al., 2004). They reported that 1 QTL affected all 5 milk production traits and was located close to marker BM143 at $50 \mathrm{cM}$ of BTA6. In the present study, the QTL found for MY, $\mathrm{FY}$, and FP were located close to this region, where several candidate genes have been identified in Bos taurus, such as ABCG2, PKD2, FAM13A1, PPARGC1A, and $O P N$ (Cohen et al., 2004; Olsen et al., 2004; Schnabel et al., 2005; Weikard et al., 2005).

The central region of BTA6 is very complex to interpret. In this region, interference might exist between different QTL, in some cases resulting from pleiotropy (Smaragdov, 2006). Ron et al. (2001) presented evidence for 5 phenotypic manifestations (MY, PY, PP, FY, and FP) of a single QTL $(48 \mathrm{cM})$ in different families of the Israeli Holstein population. Freyer et al. (2003) reported 1 pleiotropic QTL $(58 \mathrm{cM})$ that affected the production of milk protein and milk fat content in German Holstein-Friesian cattle.

In the analysis across 14 families, the $95 \%$ CI ranged from 81 to $123 \mathrm{cM}$; within the largest significant families, 95\% CI ranged from 66 to $107 \mathrm{cM}$; within family 3 , the $95 \%$ CI ranged from 22 to $104 \mathrm{cM}$; within family 4, the $95 \%$ CI ranged from 52.5 to $130 \mathrm{cM}$; and within family 9, the $95 \%$ CI ranged from 65 to $124 \mathrm{cM}$. As pointed out by Darvasi et al. (1993), the confidence interval of the QTL position on the chromosome is a very important estimate. In this study, the $95 \%$ CI were wide, which may reflect the influence of the relatively small family sizes, ranging from 20 to 127 daughters per sire (Table 1).

In the analysis within the most significant families, at 1\% chromosome-wide threshold, the QTL for MY (families 3 and 9) explained $16.76 \%$ of the BV variance; for FY (family 3) the QTL explained $19.6 \%$ of the BV variance; and for FP (families 4 and 11) the QTL explained $19 \%$ of the BV variance. Khatkar et al. (2004) identified a QTL on BTA6 for MY close to marker BM143 (53 cM) accounting for $4.18 \%$ of the total phenotypic variance.

The number of individuals genotyped in this study was smaller than all previous analyses of chromosome 6 done in US Holstein families. Because the progeny testing evaluation program in Brazilian Gyr is relatively new, the number of daughters per sire is small. Despite the genome variation between Taurus and Indicus breeds, this study was able to detect QTL affecting MY, FY, and FP at the 1\% chromosome-wide significance level in the same region found on Holstein genome (Heyen et al., 1999; Wiener et al., 2000; Ron et al., 2001; Freyer et al., 2002; Olsen et al., 2002).

This is the first chromosome scan reported not only for the Gyr breed but also for any Bos indicus dairy breed. Additional confirmation studies reporting QTL in this same region of chromosome 6 would greatly increase the applicability of MAS for milk production traits in the Gyr breed. Analysis of data from different breeds or populations might provide additional insights into the genes controlling these traits. The use of currently available high-density chips with thousands of SNP markers could also aid in mapping the QTL precisely.

\section{ACKNOWLEDGMENTS}

This work was supported by Fundação de Amparo à Pesquisa do Estado de Minas Gerais (FAPEMIG, Belo Horizonte, Brazil), Conselho Nacional de Desenvolvimento Científico e Tecnológico (CNPq, Brasilia, Brazil), and Embrapa (Juiz de Fora, Brazil). The authors thank and acknowledge the team effort and the visionary work done by the late Mário Luiz Martinez, former leader of this project at Embrapa Dairy Cattle Research Center (Juiz de Fora, Brazil).

\section{REFERENCES}

Ashwell, M. S., R. D. Schnabel, T. S. Sonstegard, and C. P. van Tassell. 2002. Fine-mapping of QTL affecting protein percent and fat percent on BTA6 in a popular U.S. Holstein family. Section 09-29 in Proc. 7th WCGALP, Montpellier, France. 31:123-126.

Boichard, D., and M. P. Bishop. 1997. Detection of QTL influencing milk production and mastitis resistance with a granddaughter design in Holstein cattle: An overview. Paper in 48th Ann. Mtg. EAAP, Commissions on Genetics and Cattle Production, Vienna, Austria. EAAP, Rome, Italy.

Chen, H. Y., Q. Zhang, C. C. Yin, C. K. Wang, W. J. Gong, and G. Mei. 2006. Detection of quantitative trait loci affecting milk production traits on bovine chromosome 6 in a Chinese Holstein population by daughter design. J. Dairy Sci. 89:782-790.

Churchill, G. A., and R. W. Doerge. 1994. Empirical threshold values for quantitative trait mapping. Genetics 138:963-971. 
Cohen, M., M. Reichestein, A. Everts-van der Wind, J. Heon-Lee, M. Shani, H. A. Lewin, J. I. Weller, M. Ron, and E. Seroussi. 2004 Cloning and characterization of FAM13A1-A gene near a milk protein QTL on BTA6: Evidence for population-wide linkage disequilibrium in Israeli Holsteins. Genomics 84:374-383.

Darvasi, A., A. Weinreb, V. Minke, J. I. Weller, and M. Soller. 1993. Detecting marker QTL gene effect and map location using a saturated genetic map. Genetics 134:943-951.

Freyer, G., C. Kühn, R. Weikard, Q. Zhang, M. Mayer, and I. Hoeschele. 2002. Multiple QTL on chromosome 6 in dairy cattle affecting yield and content traits. J. Anim. Breed. Genet. 119:69-82.

Freyer, G., P. Sorensen, C. Kuh, R. Weikard, and I. Hoeschele. 2003. Search for pleiotropic QTL on chromosome BTA6 affecting yield traits for milk production. J. Dairy Sci. 86:999-1008.

Georges, M., D. Nielsen, M. Mackinnon, A. Mishra, R. Okimoto, A. T. Pasquino, L. S. Sargent, A. Sorensen, M. R. Steele, X. Zhao, J. E. Womack, and I. Hoeschele. 1995. Mapping quantitative trait loci controlling milk production in dairy cattle by exploiting progeny testing. Genetics 139:907-920.

Green, P., K. Falls, and S. Crooks. 1990. CRI-MAP Documentation, version 2.4. http://linkage.rockefeller.edu./soft/crimap/

Haley, C. S., and S. A. Knott. 1992. A simple regression method for mapping quantitative loci in line crosses using flanking markers. Heredity 69:315-324.

Henderson, C. R. 1984. Applications of Linear Models in Animal Breeding. University of Guelph, Guelph, Ontario, Canada.

Heyen, D. W., J. I. Weller, M. Ron, M. Band, J. E. Beever, E Feldmesser, Y. Da, G. R. Wiggans, P. M. VanRaden, and H. A. Lewin. 1999. A genome scan for QTL influencing milk production and health traits in dairy cattle. Physiol. Genomics 1:165-175.

Ihara, N., A. Takasuga, K. Mizoshita, H. Takeda, M. Sugimoto, Y. Mizoguchi, T. Irano, T. Itoh, T. Watanabe, K. M. Reed, W. M. Snelling, S. M. Kappes, C. W. Beattie, G. L. Bennett, and Y. Segimoto. 2004. A comprehensive genetic map of the cattle genome based on 3802 microsatellites. Genome Res. 14:1987-1998.

Khatkar, M. S., P. C. Thomson, I. Tammen, and H. W. Raadsma. 2004. Quantitative trait loci mapping in dairy cattle: Review and meta-analysis. Genet. Sel. Evol. 36:163-190.

Kim, J. J., F. Farnir, J. Savell, and J. F. Taylor. 2003. Detection of quantitative trait loci for growth and beef carcass fatness traits in a cross between Bos taurus (Angus) and Bos indicus (Brahman) cattle. J. Anim. Sci. 81:1933-1942.

Knott, S. A., J. M. Elsen, and C. S. Haley. 1996. Methods for multiplemarker mapping of quantitative trait loci in half-sib populations. Theor. Appl. Genet. 93:71-80.

Kühn, C., G. Freyer, R. Weikard, T. Goldammer, and M. Schwerin. 1999. Detection of QTL for milk production traits in cattle by application of a specifically developed marker map of BTA6. Anim. Genet. 30:333-340.

Lipkin, E., M. O. Mosig, A. Darvasi, E. Ezra, A. Shalom, A. Friedmann, and M. Soller. 1998. Quantitative trait locus mapping in dairy cattle by means of selective milk DNA pooling using dinucleotide microsatellite markers: Analysis of milk protein percentage. Genetics 149:1557-1567.

Martinez, M. L., R. S. Verneque, R. L. Teodoro, M. V. Silva, A. E. Filho, M. A. Machado, A. R. Fernandes, and C. H. Machado. 2005. Programa Nacional de Melhoramento do Gyr Leiteiro. Resultados do teste de progênie $-13^{\circ}$ grupo. Embrapa Gado de Leite, Juiz de Fora, MG, Brazil.

Nadesalingam, J., Y. Plante, and J. P. Gibson. 2001. Detection of QTL for milk production on chromosome 1 and 6 of Holstein cattle. Mamm. Genome 12:27-31.

Olsen, H. G., L. Gomez-Raya, D. I. Vage, I. Olsaker, and H. Klungland. 2002. A Genome scan for quantitative trait loci affecting milk production traits in Norwegian dairy cattle. J. Dairy Sci 85:3124-3130

Olsen, H. G., S. Lien, M. Gautier, H. Svendsen, H. Nilsen, A. Roseth, P. R. Berg, K. K. Sundsaasen, M. Svendsen, and T. H. E. Meuwissen. 2005. Mapping of a milk production quantitative trait locus to a 420-kb region on bovine chromosome 6 . Genetics 169:275-283.

Olsen, H. G., S. Lien, M. Svendsen, H. Nilsen, and A. Roseth. 2004 Fine mapping of milk production QTL on BTA6 by combined linkage and linkage disequilibrium analysis. J. Dairy Sci. 87:690698.

Ron, M., Y. Blank, M. Band, E. Ezra, and J. I. Weller. 1996. Misidentification rate in the Israeli dairy cattle population and its implications for genetic improvement. J. Dairy Sci. 79:676-681.

Ron, M., E. Feldmesser, M. Golik, I. Tager-Cohen, D. Kliger, V. Reiss, R. Domochovsky, O. Alus, E. Seroussi, E. Ezra, and J. I. Weller. 2004. A complete genome scan of the Israeli Holstein population for quantitative trait loci by a daughter design. J. Dairy Sci $87: 476-490$.

Ron, M., D. Kliger, E. Feldmesser, E. Seroussi, E. Ezra, and J. I. Weller. 2001. Multiple quantitative trait locus analysis of bovine chromosome 6 in the Israeli Holstein population by daughter design. Genetics 159:727-735.

Sambrook, J., and D. W. Russel. 2001. Molecular Cloning: A Laboratory Manual. 3rd ed. Cold Spring Harbor Laboratory Press, Woodbury, NY.

Santiago, A. A. 1985. O zebu na Índia, no Brasil e no mundo. Instituto Campineiro de Ensino Agrícola, Campinas, Brazil.

Schnabel, R. D., J. J. Kim, M. S. Ashwell, T. S. Sonstegard, C. P. van Tasell, E. E. Connor, and J. F. Taylor. 2005. Fine-mapping milk production quantitative trait loci on BTA: Analysis of the bovine osteopontin gene. Proc. Natl. Acad. Sci. USA 102:6896-6901.

Seaton, G., J. Hernandez, J. A. Grunchec, I. White, J. Allen, D. J. D E. Koning, W. Wei, D. Berry, C. Haley, and S. Knott. 2006. A grid portal for QTL mapping of compute intensive datasets. Proc. 8th WCGALP, Belo Horizonte, MG, Brazil

Smaragdov, M. G. 2006. Genetic mapping of loci responsible for milk production traits in dairy cattle. Russ. J. Genet. 42:1-15.

Spelman, R. J., W. Coppieters, L. Karim, J. A. M. van Arendonk, and H. Bovenhuis. 1996. Quantitative trait loci analysis for 5 milk production traits on chromosome 6 in the Dutch Holstein-Friesian population. Genetics 144:1799-1808.

Velmala, R., J. Vilkki, K. Elo, and A. Mäki-Tanila. 1999. A search for quantitative trait loci for milk production traits on chromosome 6 in Finnish Ayrshire cattle. Anim. Genet. 30:136-143.

Verneque, R. S., M. G. Peixoto, A. E. Filho, M. A. Machado, M. V Barbosa, A. R. Fernandes, and C. H. Machado. 2009. Programa Nacional de Melhoramento de Gyr Leiteiro-Sumario Brasileiro de touros-resultado do teste de progênie. Embrapa Gado de Leite, Juiz de Fora, MG, Brazil.

Weikard, R., C. Kühn, T. Goldammer, G. Freyer, and M. Schwerin 2005. The bovine PPARGC1A gene: Molecular characterization and association of a SNP with variation of milk fat synthesis. Physiol. Genomics 21:1-13.

Weller, J. I., Y. Kashi, and M. Soller. 1990. Power of "daughter" and "granddaughter" designs for genetic mapping of quantitative traits cattle using genetic markers. J. Dairy Sci. 73:2525-2537.

Wiener, P., I. Maclean, J. L. Williams, and J. A. Wooliams. 2000. Testing for the presence of previously identified QTL for milk production traits in new populations. Anim. Genet. 31:385-395.

Zhang, Q., D. Boichard, I. Hoeschele, C. Ernst, A. Eggens, B. Murkve, M. Pfister-Genskow, L. A. Witte, F. E. Grignola, P. Uimari, G. Thaller, and M. D. Bishop. 1998. Mapping quantitative trait loci for milk production and health of dairy cattle in a large outbred pedigree. Genetics 149:1959-1973. 